\title{
Structures, Deformation Mechanisms and Tectonic Phases, Recorded in Paleoproterozoic Granitoids of West African Craton, Southern Part: Example of Kan's Complex (Central of Côte d'Ivoire)
}

\author{
K. K. Jean Marie Pria, \\ Laboratoire de Géologie du Socle et de Métallogénie, UFR-STRM, \\ Université Félix Houphouët-Boigny de Cocody, Abidjan, Côte d'Ivoire \\ Laboratoire des Géosciences et Environnement, Département de Géologie, \\ Université Ibn Tofaïl de Kénitra, Maroc \\ Yacouba Coulibaly, \\ N. N'guessan Houssou, \\ M. Ephrem Allialy, \\ T. K. L. Dimitri Boya, \\ Laboratoire de Géologie du Socle et de Métallogénie, UFR-STRM, \\ Université Félix Houphouët-Boigny de Cocody, Abidjan, Côte d'Ivoire

\section{Mohamed Tayebi, Lamia Erraoui, Souad M'Rabet,}

Laboratoire des Géosciences et Environnement, Département de Géologie, Université Ibn Tofaïl de Kénitra, Maroc

Doi: 10.19044/esj.2019.v15n18p315 URL:http://dx.doi.org/10.19044/esj.2019.v15n18p315

\begin{abstract}
The granito-gneissic complex of Kan is located in the central part of the Paleoproterozoic domain of Côte d'Ivoire. It consists essentially of migmatitic and mylonitic gneisses with basic intrusions and xenoliths. This Proterozoic domain belongs to the Man Leo shield, southern part of West African craton (WAC). The present study, essentially based on a structural analysis at outcrop scale, aims to identify deformation mechanisms and tectonic phases recorded in the granito-gneissic complex of Kan. Deformation mechanisms include: (1) flattening, (2) constriction, (3) simple shear (4), rotation (5), brittle shear, and (6) extension. The Kan complex deformation occurred during four major tectonic phases named D1, D2, D3 and D4. D1 corresponds to WNW-ESE compression. It led to the formation of NS to NNE-SSW foliation, of stretching lineation, and of folds with sub-horizontal
\end{abstract}


axes. It is accompanied by $\mathrm{N} 170^{\circ}$ and $\mathrm{N} 10^{\circ}$ sinistral shear zones, which constitute globally a NS major transcurrent shear zone in the central part of Côte d'Ivoire. D1 is also marked by $\mathrm{N} 90^{\circ}$ dextral shear zones. Tectonic phase D2 is associated with EW compression. It is marked by $\mathrm{N}^{\circ} 0^{\circ}$ dextral and $\mathrm{N} 110^{\circ}$ sinistral transcurents shear zones. D3 corresponds to NNE-SSW compressive phase and is responsible of $\mathrm{N} 110^{\circ}$ crenulation cleavage formation. D4 constitutes a brittle deformation phase. It corresponds to posteburnean deformation in the Proterozoic crust of Côte d'Ivoire. Generally, these deformation phases are similar to D2 and D3 reported in the Man-Leo shield and that are part of regional collisional phase referred to as Eburnean orogeny in the WAC.

Keywords: Deformation, Gneiss, Paleoproterozoic, Côte d'Ivoire, West African Craton

\section{Introduction}

The Paleoproterozoic or Baoulé-Mossi crust of Côte d'Ivoire belongs to the southern West African craton (WAC) (Figs 1 and 2). It is composed of volcano-sedimentary rocks, metasediments and granitoids (Yace, 1982). Within granitoids, occurs the granito-gneissic complex of Kan, which is subject of the present study. It is located in the central part of Côte d'Ivoire precisely between the volcano-sedimentary belt of Toumodi- Fètèkro in the east and the metasediments of Comoé in the west (Fig. 3). It extends over a length of $100 \mathrm{~km}$ and an average width of $20 \mathrm{~km}$ (Daouda, 1998). Previous works on the complex of Kan have been devoted to understanding its relationship with volcano-sedimentary rocks and adjacent metasediments. Mortimer $(1990,1992)$ argues that the Kan's complex is the equivalent of the Dabakala gneisses (north of Côte d'Ivoire) assimilated to Burkinian (2.4-2.15 Ga) (Lemoine, 1988). He shows that it constitutes the Burkinian substratum of the basin rocks and defines structural contacts at the eastern and western boundaries respectively with the Comoé basin and the volcanic rocks of Toumodi. Daouda (1998), based on structural and metamorphic studies at the eastern boundary of the Toumodi-Fètèkro volcano-sedimentary belt, shows that the granito-gneissic complex of Kan has subsequently developed into the basin formations in a strike-slip shear zone. Therefore, it does not constitute the Burkinian substratum of the basin rocks. He indicates that this complex is a syntectonic granitoid set up in a transcurrent system. Although some structural aspects of the granito-gneissic complex of Kan are addressed by previous studies, others such as 


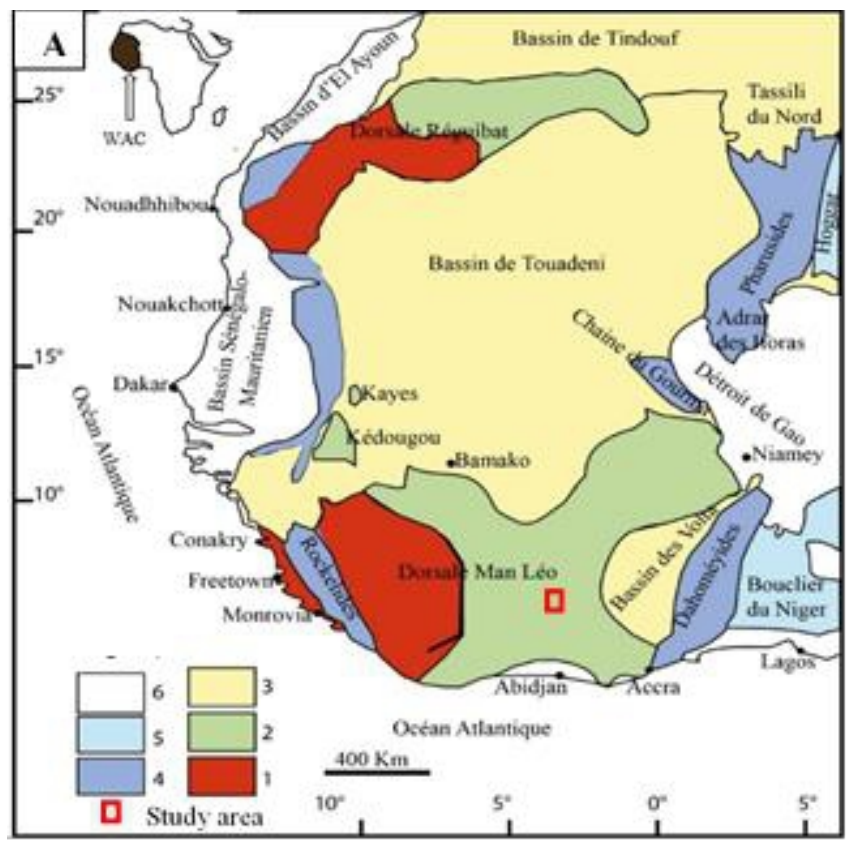

Figure 1: Geological sketch map of West African Craton, modified (after Trumpet 1973) with location of the study area

1: Archean; 2: Birimian; 3: Paleozoic basins locally encompassing the upper Precambrian;

4: Mobile areas; 5: Post-Neoproterozoic Lands; 6: Post-Paleozoic lands;

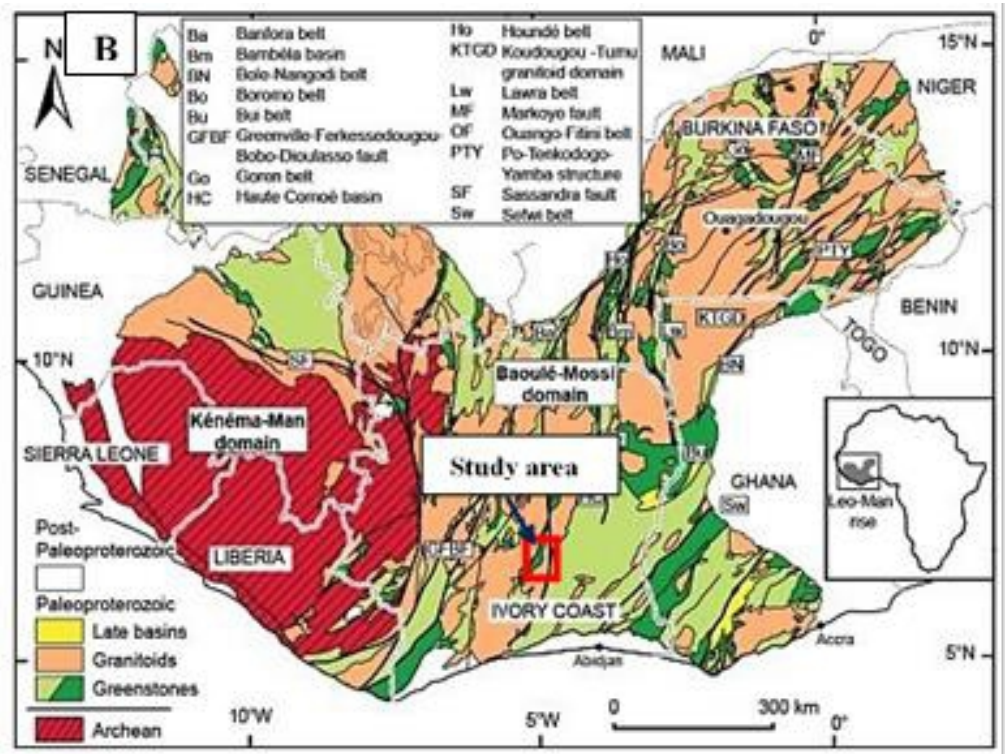

Figure 2: Geological sketch map of the Man-Leo shield (modified from the BRGM SIGAfrique map, Milési et al., 2004) with location of the study area.

the mechanisms and tectonic phases are less well known. Thus, this work aims to provide new data on the deformation mechanisms of the Kan's 
complex. It will help to identify the different tectonic phases recorded in this part of Proterozoic crust of Côte d'Ivoire in order to situate them in the general context of the West African Craton deformation.

\section{Geological context}

The Precambrian crust of Côte d'Ivoire, comprises two main domains of different ages. Those are the Archean domain to the west and the Proterozoic domain to the east, separated by the NS fault of Sassandra (Bessoles, 1977). The Archean domain was structured during two major orogenic cycles: the Leonian $(3.3 \mathrm{Ga}$ to $3.0 \mathrm{Ga})$ and the Liberian $(2.9 \mathrm{Ga}$ to 2.7 Ga), (Yace, 1984; Kouamelan, 1996; Pothin et al., 2000; Pitra et al., 2010). This domain includes high-grade metamorphic units such as granulitic gray gneisses and charnockites. The Proterozoic domain, to which the Kan complex belongs, was structured by the Eburnean megacycle. This domain contains Birimian age rocks considered to be an episode of crustal creation between 2.5 $\mathrm{Ga}$ and 2.1 Ga (Abouchami et al., 1990, Boher et al., 1992). The Birimian rocks form volcano-sedimentary belt generally oriented NNE-SSW and bordered or intruded by granitoids.

Polyphase deformation have been reported in the Birimian crust of the southern West African Craton (WAC). The first one (D1) is attributed to collision tectonic at 2,1 Ga. It contributed to the cratonisation of terrane around the Archean nuclei. The early Proterozoic was placed in thrust contact with the Archean basement. (Feybesse et al., 1989). The second and third (D2 and D3) phases are related to major transcurent tectonics (Milési et al., 1992). They correspond to a new compressive phase and affected the whole Birimian series. The D2 deformation is marked by NS to NNE-SSW sinistral strike-slip faults that are locally associated with SE vergin thrust zone. The D3 deformation is related to NE-SW dextral strike-slip faults.

Others studies in the Birimian of southern WAC, have attributed regional deformation events to collisional phase (Baratoux et al., 2011; Perrouty et al., 2012; Block et al., 2016a, 2016b; Masurel et al., 2017; Grenholm et al., 2019). The compilation of published studies on deformation events during collisional phase, highlighted that early events (2160-2120 Ma) are many times associated with $\mathrm{N}-\mathrm{S}$ oriented compression or extension, whereas subsequent deformation (2120-2070 Ma) is dominantly associated with NW-SE compression (Grenholm et al., 2019). 


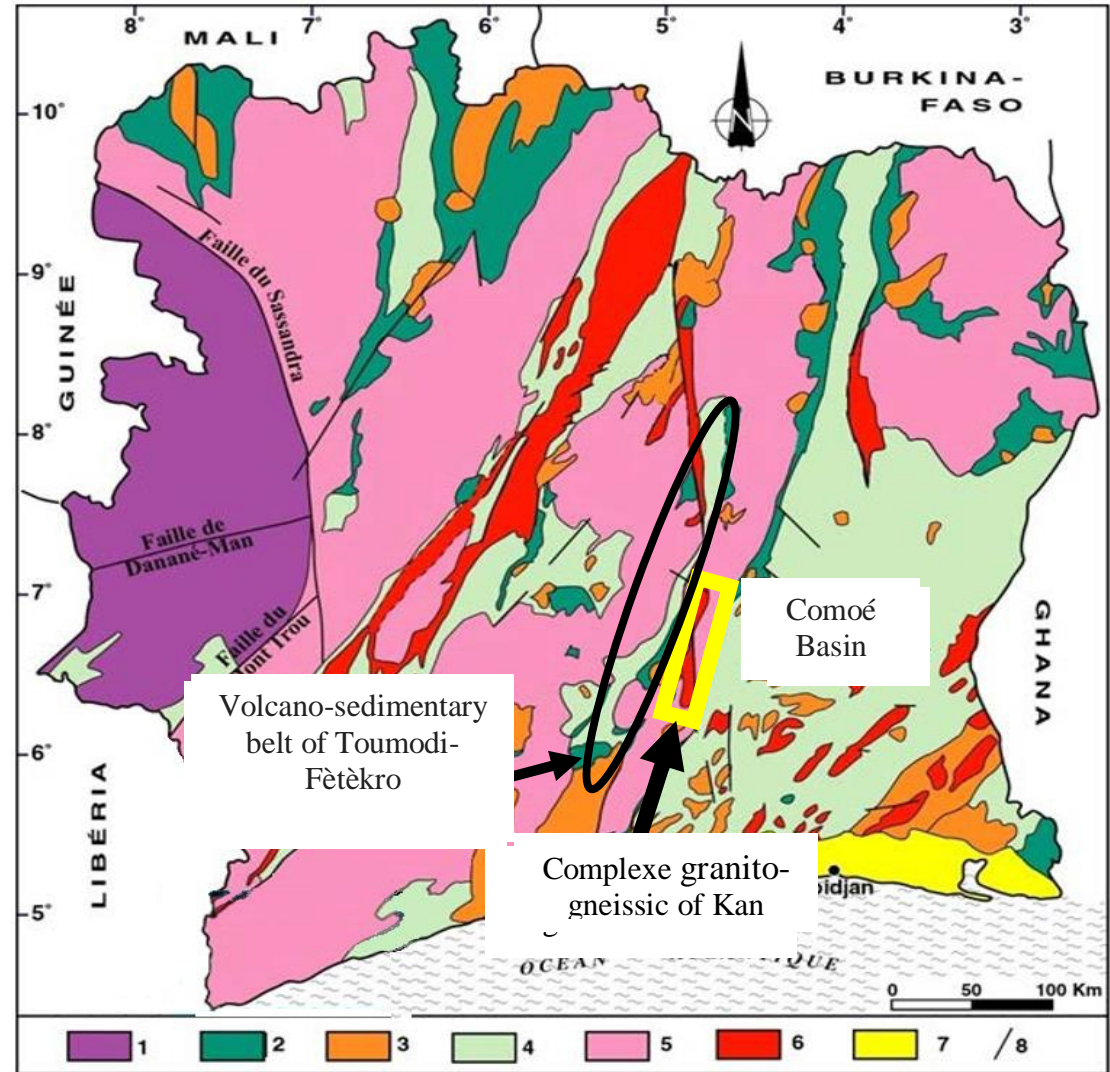

Figure 3: Geological sketch map of Côte d'Ivoire, (Kouamelan, 1996) locating the study area.

$1=$ Archean domain; $2=$ volcanites; 3 = granitoids of the greenstone belt type;

$4=$ sedimentary basins; $5=$ undifferentiated granitoids; $6=$ granitoids with two micas of basin type; $7=$ post-Birimian formations; $8=$ major fractures

\section{Material and methods}

This study, essentially based on a structural analysis at outcrop scale, began with a field mission conducted by geologists team from the Laboratoire de Géologie du Socle et de Métallogénie of Université Felix HouphouëtBoigny of Côte d'Ivoire. It consisted in recognizing and describing all the mesostructures of deformation at outcrop scale, taking into account their geometries. The orientation (Strike, dip/plunge) of the different structures have been measured by using Sylva type compasses. The most beautiful structures were photographed. The laboratory works took place in the Laboratoire de Geosciences et Environnement of Université Ibn Tofaïl of Kénitra-Maroc. Firstly, it consisted of exporting the measurements obtained in the form of a text file to stereonet software which allowed to construct directional rosettes. Secondly, interpretations of the different structures were 
made and were focused on the mechanisms and tectonic events responsible for their formations.

\section{Results}

\section{Folds}

Gneissic rocks are affected by various types of folds at outcrop scale. Folds with subhorizontal axes are more represented. They occur in migmatitic gneisses and mainly affect granitic leucosome veins (Fig. 4A). Foliation is parallel to the axial planes of folds and is represented microscopically by fine glitter oriented recrystallization biotite. The axial planes are vertical and the folds axes dip slightly from $5^{\circ}$ to $10^{\circ} \mathrm{S}$. Intrafoliar folds are also common in gneisses. Their axial planes are subparallel to the foliation and they show subvertical axes. These folds are markers of shearing (Passchier and Trouw, 2005). They comprise "S" type and "Z" type and mark respectively sinistral and dextral shearing (Fig. 4B and 4C). Sinistral shearing affects some folds limbs and leads to Rootless folds (Fig. 4D). These folds appear as the manifestation of a high intensity shearing. Others folds such as similar folds with vertical axes and axial planes oriented N10-40 $\mathrm{E}$ (Fig. 4D), sheath folds and Kink folds are also common in the gneissic rocks. Hinge zones and limbs of large symmetrical folds of incompetent leucogranitic layers produced by gneiss melting, display parasitic or subsidiary folds (Fig. 4E). Parasitic folds in the limbs are ' $Z$ ' folds and ' $S$ ', folds whereas those in the hinge are symmetrical ' $M$ ', folds. Their axial planes are parallel to the major folds ones and measure $\mathrm{N} 10^{\circ}$.

\section{Foliation}

Foliation is characterized by alternating of centimetric quartzofeldspathic and ferromagnesian bands (Figure 5A). It is well developed in migmatitic gneisses. Foliation is subvertical $\left(70^{\circ} \mathrm{E}\right)$ (Fig. 5A). Stereographic projection shows NS to NNE-SSW main direction (Fig. 8A). Its plane carries a subhorizontal lineation with a shallow plunge ranging from $5^{\circ}$ to $10^{\circ} \mathrm{N}$ (Figure 5B). That lineation is due to the stretching of quartz, feldspar amphibole and biotite. The simultaneous presence of foliation and lineation confers an "SL" fabric to the gneisses of the Kan complex and particularly to the migmatitic gneisses. This fabric appears as the consequence of simple shear.

\section{Stretching lineation}

Stretching lineation is materialized by the stretching of quartz, feldspar, amphibole, micas, but also by basic xenoliths (Fig. 6A). It constitutes the main fabric of mylonitic gneisses. 

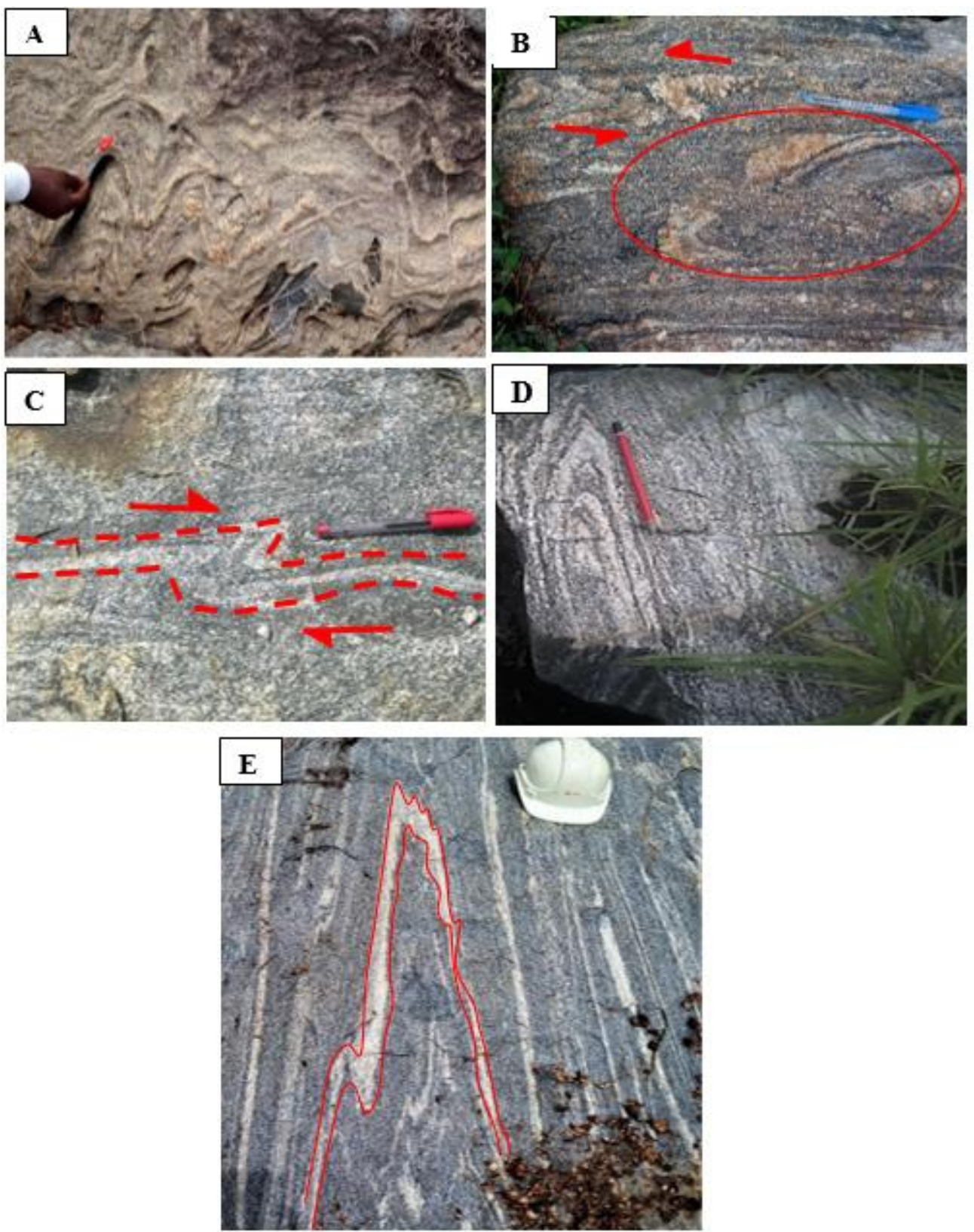

Figure 4 : Photograph of folds at outcrop scale in the gneissic rocks.

A: Folds with subhorizontal axes; $\mathbf{B}$ : Similar folds; C: Symmetrical major folds with parasitic Z, S and $\mathrm{M}$ folds sitting respectively in the left limb, right limb and in the hinge.

Note foliation parallel to axial plane; D: Intrafoliar " $S$ " folds and rootless fold; $\mathbf{E}$ : intrafoliar "Z" fold. 

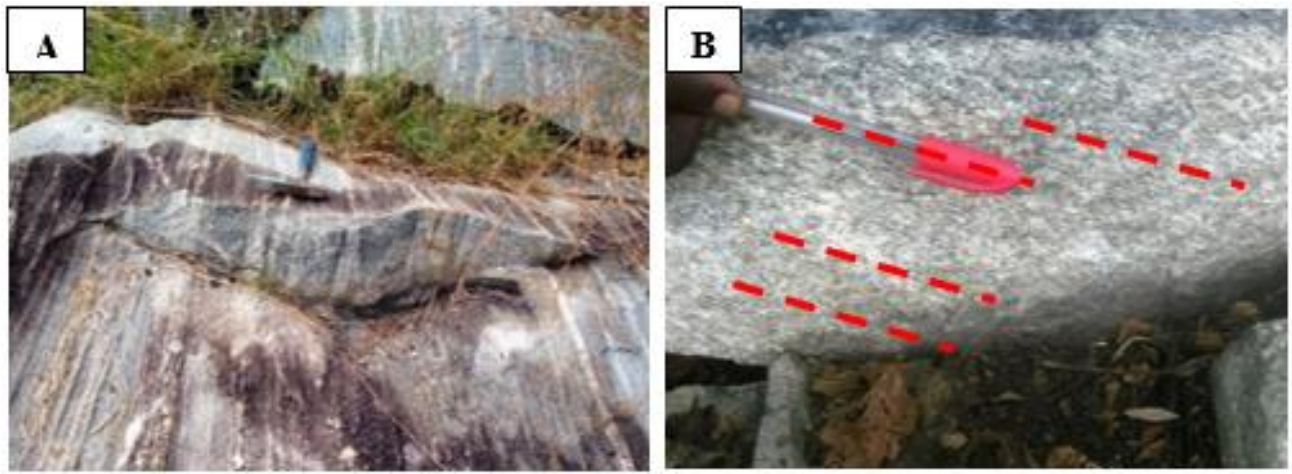

Figure 5 : Photograph showing subvertical foliation (A) with subhorizontal mineral lineation $(\mathrm{B})$ in migmatitic gneiss.
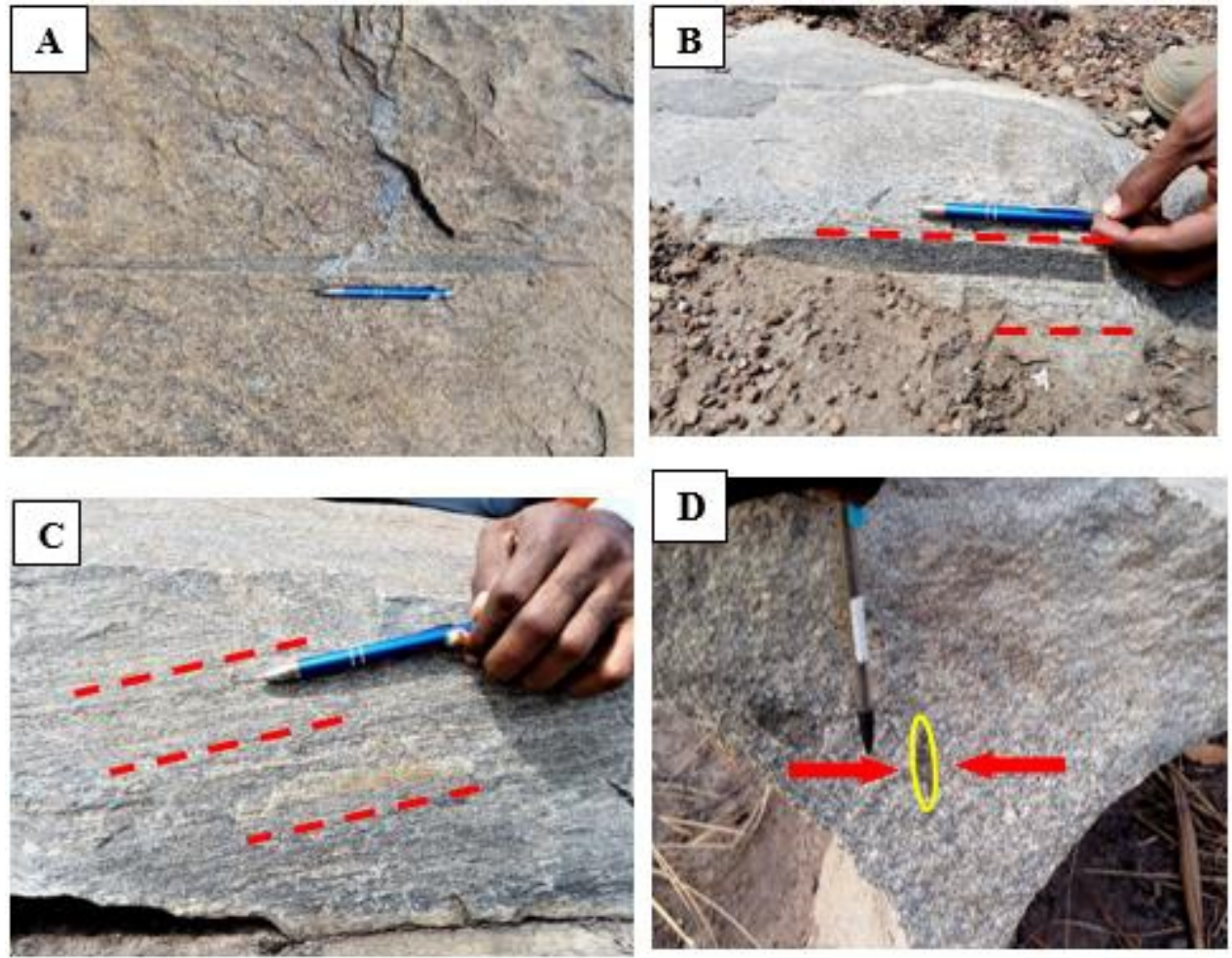

Figure 6: Photograph showing stretching lineations in the gneissic rocks.

A:Mineral stretching; B: Stretching of basic xenolith; C:Stretching lineation showing subhorizontal plunge; D: Basic xenolith showing deformation by flattening in XZ plane of strain ellipsoid.

Mylonitic gneisses are characterized by prominent stretching lineation and can be consider as L- tectonites. Along a West-East profile, L tectonites are observed to the western an eastern part of the study area in mylonitic gneisses. They are relayed by the "SL" fabric in the central part 
within migmatitic gneisses which show strong ductile deformation. Stretching lineation shows subhorizontal plunge (Fig. 6B, 6C). Stereographic projection gives NS to NNE-SSW principal direction (Fig. 8B). In the YZ plane of the strain ellipsoid, basic xenoliths often are flattened (Fig. 6D).

\section{Shear bands and $\mathrm{S} / \mathrm{C}$ structures}

Rocks in the study area are affected by significant shearing (Fig. 7A7F). Five main shear bands directions have been identified. They are $\mathrm{N} 10^{\circ}$, $\mathrm{N} 170^{\circ}, \mathrm{N} 050^{\circ}, \mathrm{N} 90^{\circ}$ and $\mathrm{N} 110^{\circ}$. The $\mathrm{N} 10^{\circ}, \mathrm{N} 170^{\circ}$ and $\mathrm{N} 110^{\circ}$ shear bands are sinistral while the $\mathrm{N}^{\circ} 50^{\circ}$ and $\mathrm{N} 090^{\circ}$ directions indicate dextral sense. The $\mathrm{N} 170^{\circ}$ direction appears abundant in the study area according to the stereographic projection (Fig. 8C). That shear band $\left(\mathrm{N} 170^{\circ}\right)$ superimposed the shearing direction given by the $\mathrm{S} / \mathrm{C}$ structures. The latter one is observable in gneissic rocks but also in micaschists at the eastern boundary of Kan complex. $\mathrm{S}$ plane is oriented $\mathrm{N} 10^{\circ}$ and corresponds to the foliation while the $\mathrm{C}$ plane is oriented $\mathrm{N} 170^{\circ}$ (Fig. $7 \mathrm{~F}$ ). Shear bands planes carry subhorizontal mineral lineation with weak plunge $\left(10^{\circ} \mathrm{N}\right)$. This lineation is similar to the mineral lineation carried by the foliation plane.

\section{Porphyroclasts, boudins and crenulation cleavage}

Porphyroclasts are essentially feldspathic and quartzic. They are well developed in gneisses and in pegmatite veins. They are mainly represented by the delta type $(\delta)$ (Fig. 9A) according to the classification of Passchier and Trouw, (2005). This structure with monoclinic symmetry belongs to the main markers of NS to NNE- SSE shearing in the study area. However, some $\theta$-type with orthorhombic symmetry were observed. The sigma type $(\sigma)$ with monoclinic symmetry indicating dextral shear is more rarely seen. In addition to ductile deformation, porphyroclasts are often affected by antithetic microfractures, leading to domino boudins.

Boudins in the granito-gneissic complex of Kan are either asymmetric or symmetric. The first ones are largely dominated by shearband boudins. However some domino boudins are also distinguished and affect feldspar porphyroclasts. Shearband boudins show antithetical movement with respect to the general sinistral shearing. Symmetrical boudins no display sliding movement at their interface. They are oriented parallel to the foliation and the mineral lineation. Crenulation cleavage (S2) is produced by microfolding of the preexisting foliation (S1) (Fig. 9B) and is oriented N110 . 

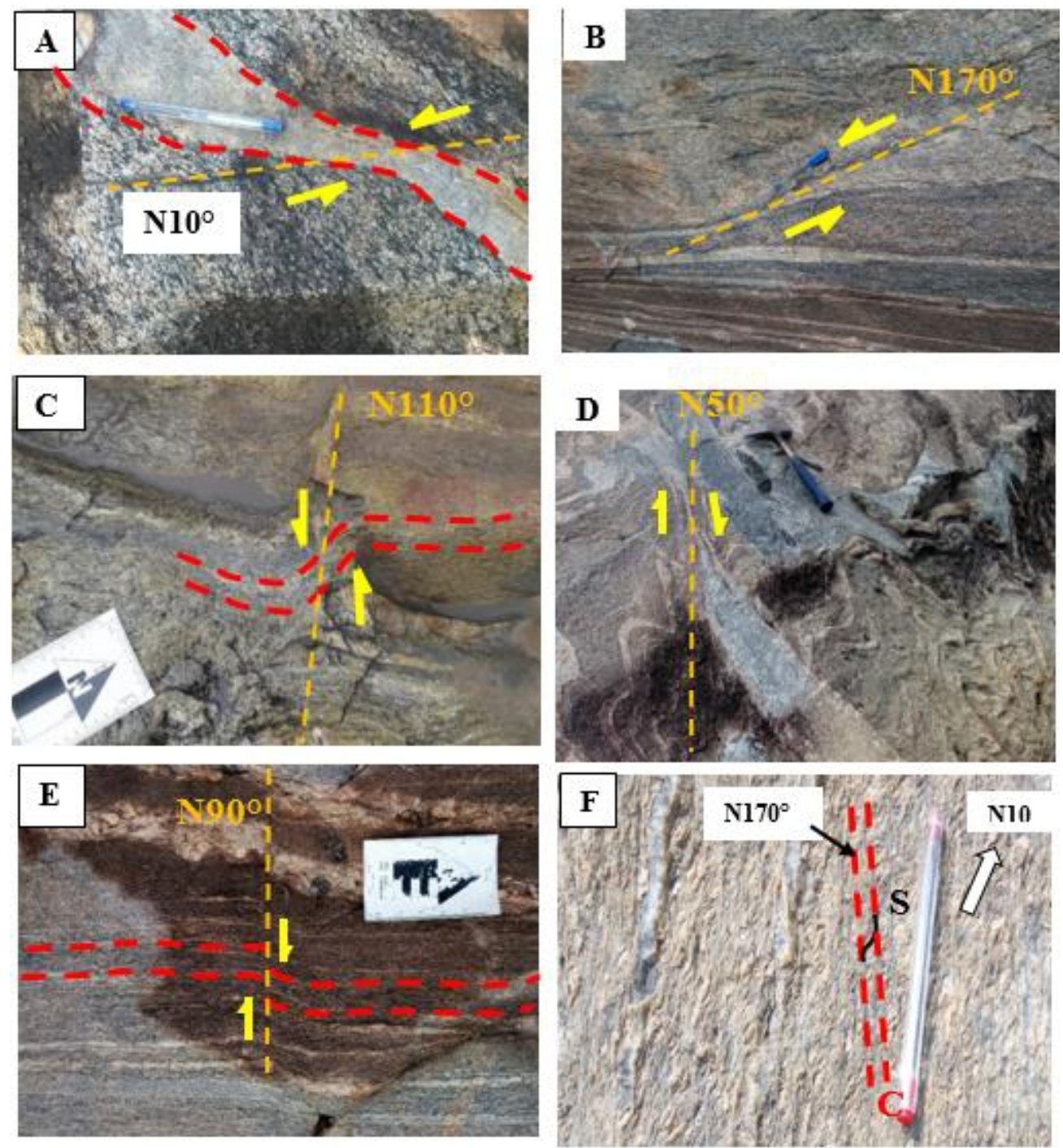

Figures 7: Photograph of the main shear bands directions in the granito-gneissic complex of Kan

A: NS Sinistral shear band; B: N170 ${ }^{\circ}$ sinistral shear band; C: N110 sinistral shear band; D: N50 ${ }^{\circ}$ dextral shear band. E: N90 dextral shear band; F: S/C structure with S plane and C plane respectively oriented $\mathrm{N} 10^{\circ}$ and $\mathrm{N} 170^{\circ}$. 


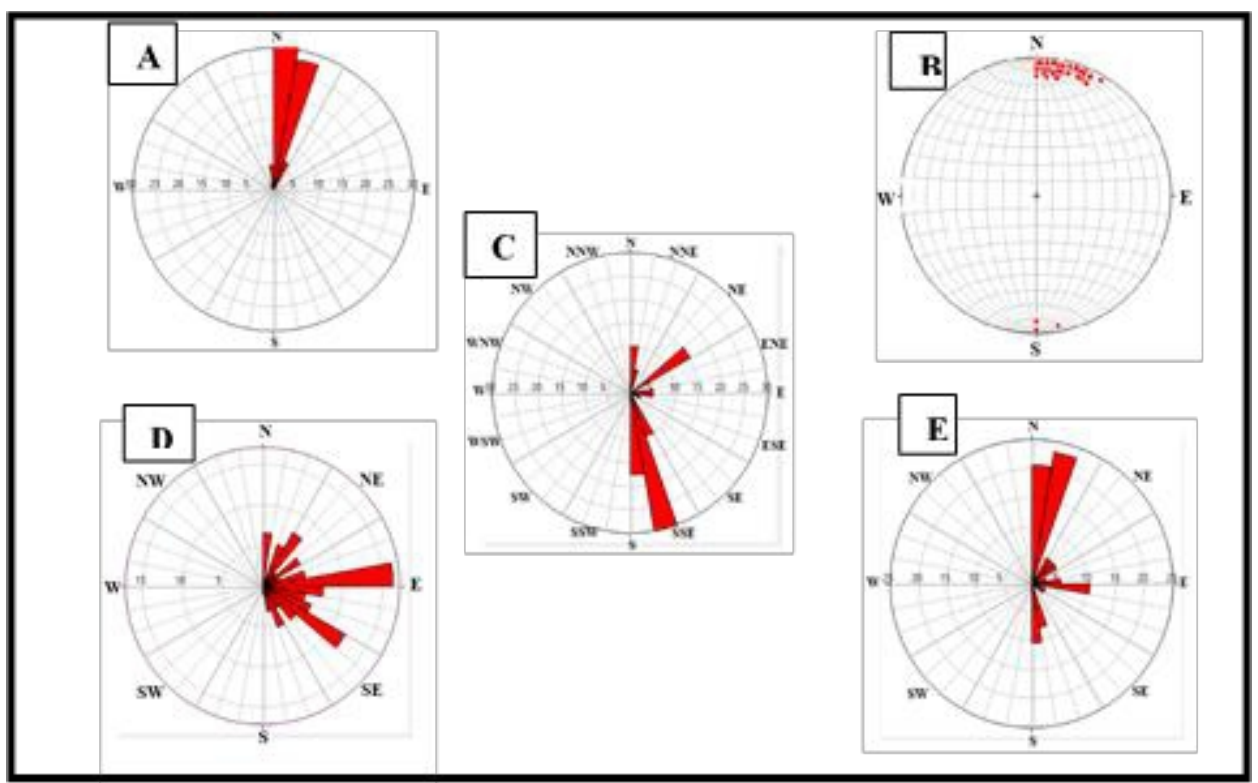

Figure 8: Stereographic projections

A: foliation; B: mineral stretching lineation; C: shear bands; D: fractures; E: quartz veins.
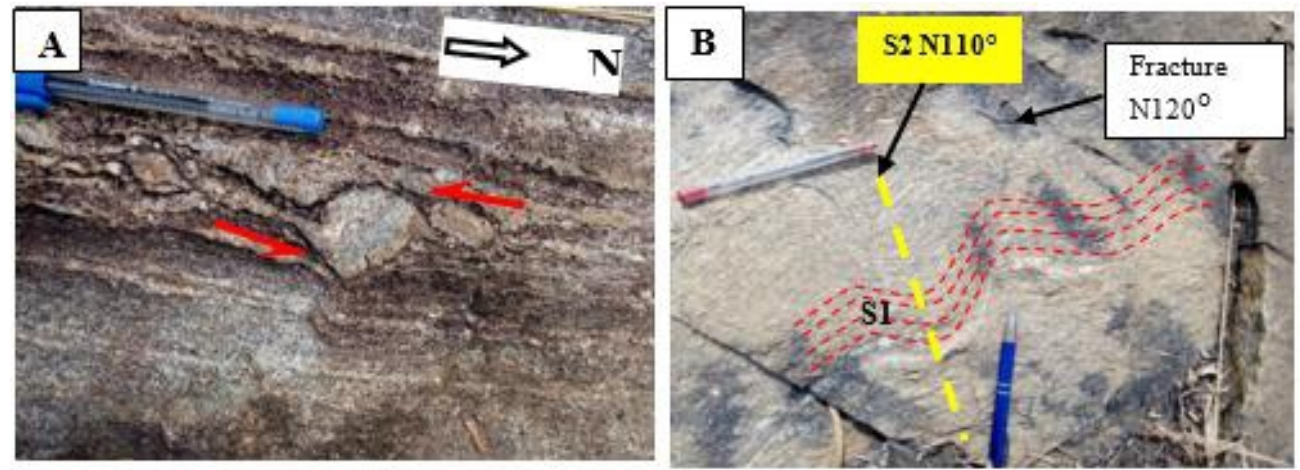

Figure 9: Photograph of delta $(\delta)$ type porphyroclast showing sinistral shearing $(\mathbf{A})$ and crenulation cleavage $(\mathbf{B})$. Note crenulation cross cutting by $\mathrm{N} 120^{\circ}$ fractures.

\section{Fractures}

Fracturing affects all lithologies in the study area. However, it is more intensified in the mylonitic gneiss at the eastern limit of the Kan complex precisely in the locality of Laourébo and no far of the N'zi river. Fractures are essentially shear fractures. They are dominated by EW and NW-SE directions (Fig 8 D) which provoke dextral displacement. In addition to these directions, NE dextral and NS fractures have affected gneissic rocks. 


\section{Quartz veins and extensional fractures}

Quartz veins are generally oriented NS (Fig. 7E), parallel to the foliation with a dip ranging from $60^{\circ} \mathrm{E}$ to $70^{\circ} \mathrm{E}$. They are similar to NS fractures and are essentially extensional veins with oblique fibers. In association with extensional fractures, they constitute NS to NNE-SSW extensional movement markers. Apart from that group of quartz veins, another group oriented EW is also distinguished. These veins are less represented in the study area and produce dextral displacements. Extensional fractures were observed mainly in the mylonitic gneisses approaching the metasedimentary rocks of Comoé basin. The recrystallization product is essentially quartzfilling. Two main directions corresponding to two different families of extensional fractures are distinguished (Fig. 10A). The first family with an oblique fibrous structures (Fig. 10B) comprises larger extensional fractures oriented $\mathrm{N} 080$ to $\mathrm{N} 100^{\circ}$. The second family with $\mathrm{N} 120^{\circ}$ to $\mathrm{N} 130^{\circ}$ orientations, comprise less larger extensional fractures. These two families are contemporary and are associated with EW compression. The second family is also formed by pull apart system.

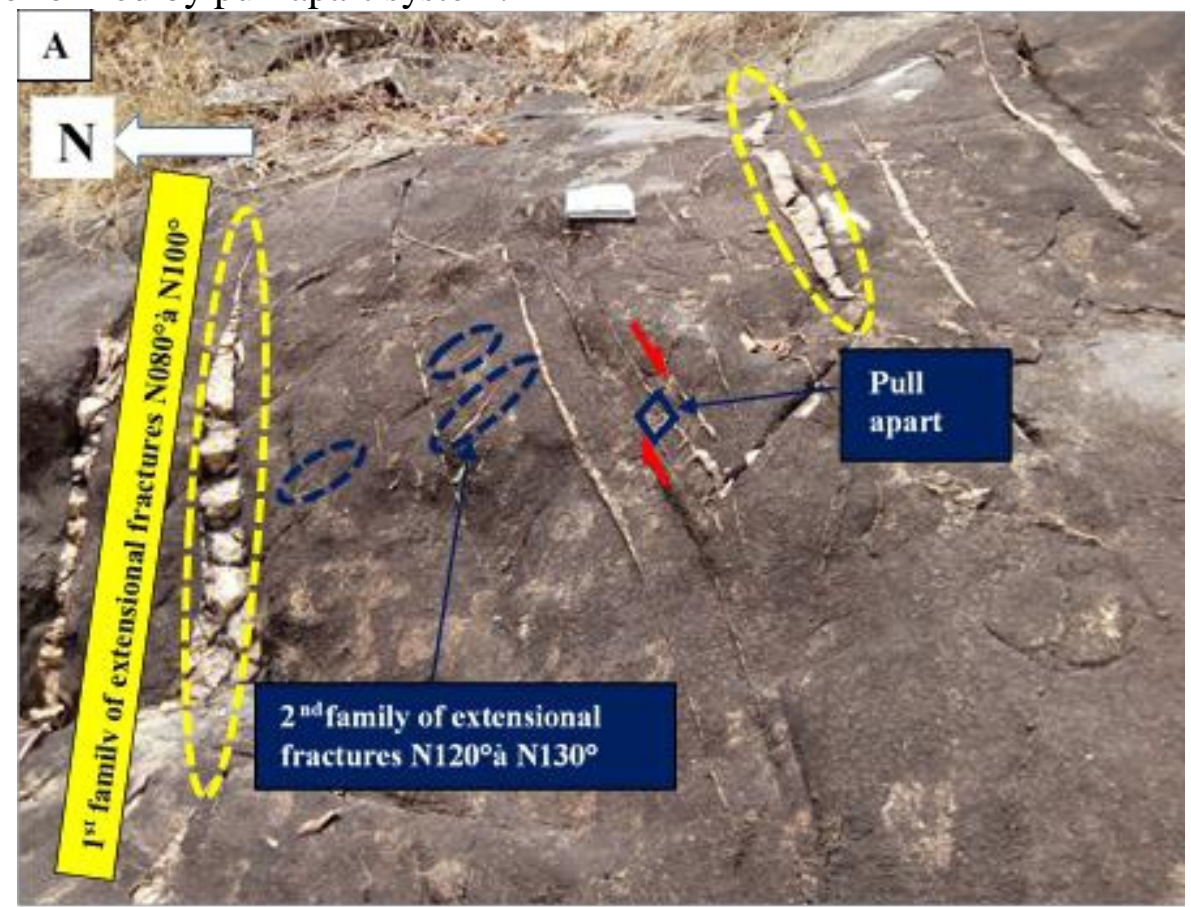




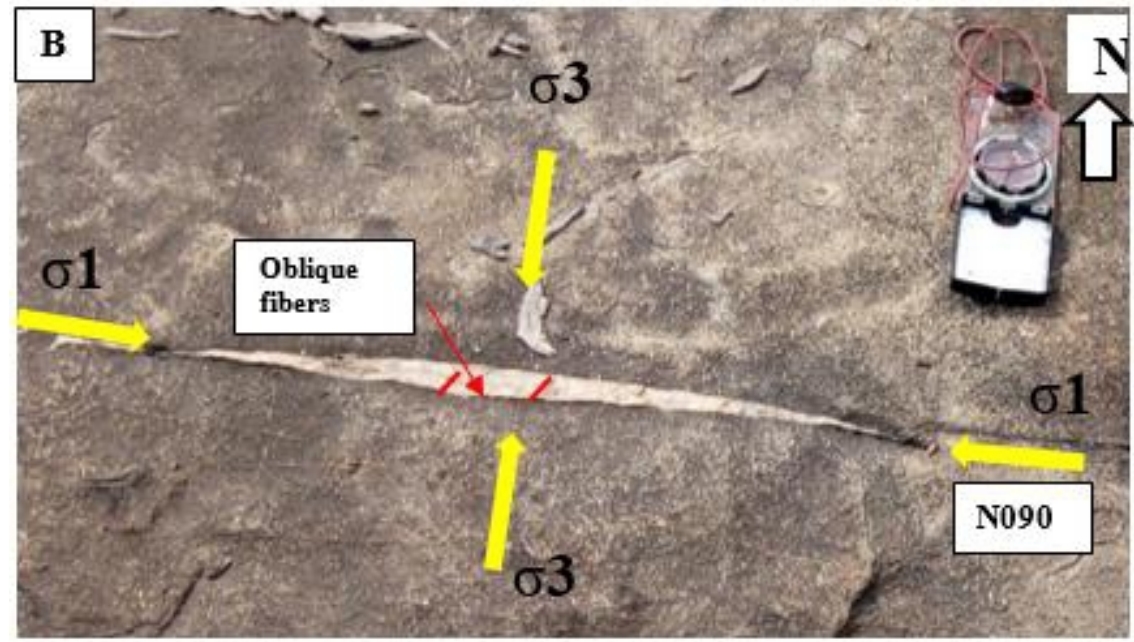

Figure 10 : Photograph showing extensional fractures in gneissic rocks.

A : EW extensional fractures and NW-SE extensional fractures;

B: EW Extensional fractures with oblique quartz fibers

\section{Discussion}

\section{Deformation mechanisms and associated tectonic events}

The foliation generally oriented NS to NNE-SSW and parallel to the axial plane of folds, is the manifestation of flattening. That deformation occurs during WNW-ESE shortening. Similar folds with vertical axes and basic xenoliths flattened in the $\mathrm{XZ}$ plane of the strain ellipsoid, are also the witnesses of flattening. WNW-ESE Shortening induced constrictional deformation materialized by the mineral stretching lineations and basic xenoliths ones. On the other hand, the subhorizontal stretching lineation carried by the foliation plane and the presence of asymmetrical intrafoliar and parasitic folds are the results of transcurrent movement which occurs during a simple shear deformation. The Main direction of shearing in the granito-gneissique of Kan is globally NS and includes ( $\mathrm{N} 170^{\circ}$ and $\mathrm{N} 10^{\circ}$ directions). That shearing with sinistral sense, as materialized by S/C structures and sinistral $\mathrm{N} 170^{\circ}$ and $\mathrm{N} 10^{\circ}$ shear bands, led to rotational deformation, marked by the formation of an important delta $(\delta)$-type porphyroclasts. The presence of these asymmetry structure and rootless folds is the result of a high intensity shearing (Passchier and Trouw. 2005).Thus, the granito-gneissic complex of Kan belongs to a major sinistral NS transcurrent shear zones which can be consider as an extension in the central part, of the Brobo shear zone. This major structure (Brobo shear zone), has been described by Lemoine (1982) and Gasquet (2003) in Dabakala region (Northern part of Côte d'Ivoire). Similar NS major transcurrent shear zones are well known in the Paleoproterozoic field of the West African Craton. Examples are Sassandra fault mentioned by Bard, (1974), Wango-Fitini shear zone described by Vidal et al. (1984) in the upper 
Comoé basin and those mentioned in Kedougou area (Senegal-Mali) by Ledru et al., (1989) and Sadiola shear zone in Mali (Masurel et al., 2017). In addition to the principal NS shear zone, others, oriented $\mathrm{N} 110^{\circ}$ with sinistral sense and $\mathrm{N} 050^{\circ}, \mathrm{N} 090^{\circ}$ with dextral displacements are distinguished in the Kan's complex. Shear zones directions identified, are similar to those previously reported in the WAC (Vidal et al., 1994; Gasquet et al., 2003; McFarlane et al., 2017; Daï Bi et al., 2018; Dabo et al., 2018). These series of transcurrent deformations are all induced by WNW-ESE and EW shortenings.

Intrafoliar ' 'Z' folds with axial planes subparallel to foliation are less represented in the gneissic rocks of the Kan's complex. They are the consequence of a simple shear. They could be simultaneous to the formation of intrafoliar $\mathrm{S}$ folds or associated with a late-eburnean tectonic phase, expressing by NE-SW to NNE-SSW shortening. The last option seems more coherent with the presence of $\mathrm{N} 110^{\circ}$ crenulation cleavage. Thus NNE-SSW to NE-SW shortening would be responsible for a second NS shearing with dextral sense. That 'new' shearing, used partially the weak zone previously created by Brobo shear zone. It corresponds probably to the N'Zi shear zone previously defined by Bard (1974) in the Proterozoic crust of Côte d'Ivoire.

Brittle shear is manifested by the presence of fractures, quartz veins and extensional fractures. The setting of extensional fractures is the result of an extensional mechanism deformation (Mattauer, 1980). In addition, quartz fibrous structures are obliques to the extensional fractures margins. That means, extensional fractures opened obliquely to the extension direction (NS to NNE-SSW) given by the $\mathrm{X}$ axis of the strain ellipsoid and materialized by the stretching lineation. Dextral fractures with EW, NW-SE and NE-SE directions and NS sinistral ones appear as the late deformation affected the granito-gneissic complex of Kan.

\section{Tectonic phases}

Four tectonics phases named D1, D2, D3 and D4 are recorded in the granito-gneissic complex of Kan: D1, D2 and D3 can be related to different compressions corresponding to different positions of the principal stress $(\sigma 1)$ (Fig. 11):

The first (D1) phase corresponds to WNW-ESE compression. It is associated with the formation of subvertical NS to NNE-SSW foliation. 

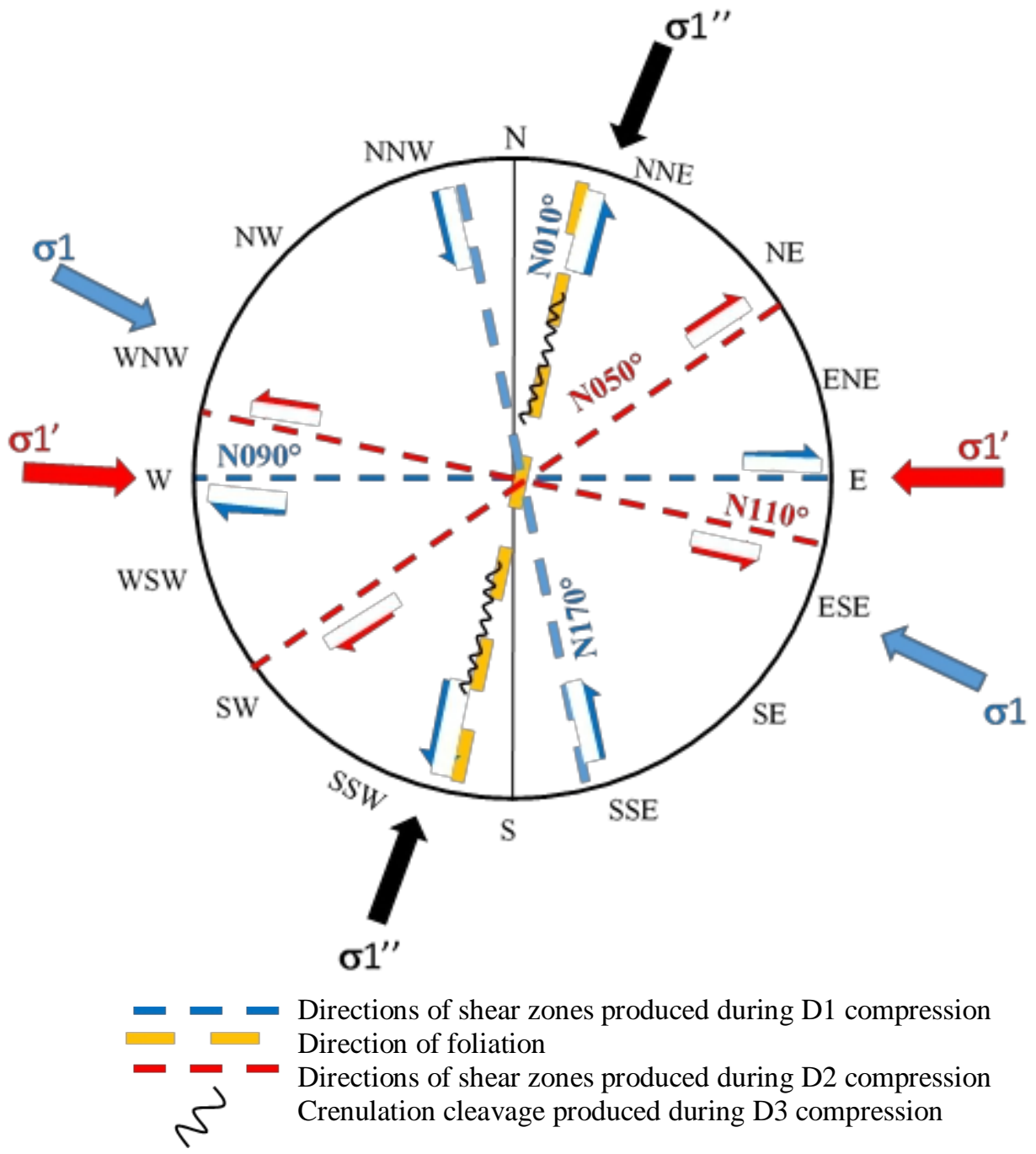

Figure 11: Sketch of the positions of the principal stress $(\sigma 1)$ and associated shear zones, during the deformation of the granito-gneissic complex of Kan.

That deformation phase is responsible of the formation of stretching lineation, of the folds with subhorizontal axes, and of symmetrical and asymmetrical boudins. It is accompanied by ductile sinistral shear zones with NNW-SSE to NNE orientation and by EW dextral shear zone.

D2 phase is associated with EW compression, after a progressive rotation of the principal stress from WNW-ESE position to EW. It is marked by NE-SW $\left(\mathrm{N} 50^{\circ}\right)$ dextral and ESE-WSW $\left(\mathrm{N} 110^{\circ}\right)$ sinistral shear zones. D1 and D2 phases identified, belong to the D2 tectonic phase that Ledru et al. (1989) mentioned in Kedougou area of Senegal-Mali. These phases are also 
similar to the D2 and D3 deformation phases reported by Milési et al., 1992 in the Birimian orogenic belt of West African craton.

D1 and D2 present the characteristics of EI and EII deformation episodes described by Lompo (1991) in the Kwademen region in Burkina Faso and the D2 deformation reported by Vidal et al. (1996) in the upper Comoé basin (Côte d'Ivoire). Baratoux et al, (2011), have related D1 deformation phase in the western Burkina Faso, to EW to WNW-ESE compression.

Dextral NE-SW shear zone has been reported in Sefwi series (Ghana), such as Ketesso (Jessell et al., 2012; McFarlane et al., 2017). The first deformation phase ( $\mathrm{Dj} 1)$, identified in the Julie gold deposit, in the northwest of Ghana, is materialized by dextral EW shear zone (Amponsah et al., 2015). In the Siguiri basin of Guinea, the main and second phase of deformation $\left(D_{2 s}\right)$ is interpreted to have been associated with EW to ENE-WSW directed compression (Lebrun et al., 2017).

D3 corresponds to a NNE-SSW compressive phase. It is marked by a N110 crenulation cleavage. This phase corroborates the third (D3) deformation phase of Vidal et al (1996) and Baratoux et al, (2011).

In the Birimian formation of Mako, eastern Senegal, a sinistral transpression with NNE-SSW shortening is identified as tectonic phase D2 and belongs to Eburnean event (Dabo et al., 2018).

Compressive phases D1, D2 and D3 are related to the collisional phase during Eburnean orogeny in the in the WAC. They there are therefore associated with the general accretionary-collisional system that extends into Réguibat shield and into equivalent crust in the Amazon craton. The D1 and D2 phases took place at around 2120-2070 Ma while D3 occurred at about $2025 \mathrm{Ma}$ (Grenholm et al., 2019).

D4 is marked by EW, NW-SE, NE-SE dextral and NS sinistral fractures. These structures are related to post-Eburnean movements (Vidal and Alric, 1994).

\section{Conclusion}

This study has shown that the deformation of the granito-gneissic complex of Kan results from different mechanisms such as flattening, constriction, simple shear accompanied by rotation, brittle shear with or without extension. This deformation occurred during four tectonic phases D1, D2, D3 and D4. The first (D1) and the second (D2) tectonic phases correspond respectively to WNW-ESE and EW compressions. They generated intraplate transcurrent shear zones, including the principal NS sinistral shear zone, which constitutes an extension of the Brobo fault in the central part of Côte d'Ivoire. These two tectonics phases are followed by a late NNE-SSW compressive phase (D3) and by a post-eburnean brittle deformation phase D4. The deformation phases recorded in the granito-gneissic complex of Kan are in 
general the results of the collisional phase during Eburnean orogeny at around 2120-2025 Ma. in the southern part of the West African craton. They are part of accretionary-collisional system that extends in the north of the WAC into Réguibat Shield.

\section{Acknowledgements}

The authors thank the administrative staff of the Unité de Formation et de Recherche en Sciences de la Terre et des Ressources Minières (UFRSTRM) of Université Félix Houphouët- Boigny, Abidjan-Côte d'Ivoire, for giving necessary material during field mission. They also thank the staff of the Laboratoire des Geosciences et Environment of the Université Ibn Tofaïl, Kénitra-Maroc for the contribution in structural data interpretation.

\section{References:}

1. Abouchami, W., Boher, M., Michard, A. \& Albarede, F., 1990. A Major 2, 1 Ga Event of Mafic Magmatism in West Africa: An Early Stage of Crustal Accretion. Journal of Geophysical Research, 95, 17605-17629.

2. Amposah, P. O., Salvi, S., Béziat, D., Siebenaller, L., Baratoux, L., \& Jessell, M. W., 2015. Gelogy and geochemistry of the shear-hosted Julie gold deposit, NW Ghana. Journal of African Earth Sciences, 112, 505-523.

3. Baratoux, L., Matelka, V., Naba, S., Jessell, M. W., Grégoire, M., \& Ganne, J., 2011. Juvenile Paleoproterozoic crust evolution during the Eburnean orogeny (2.2-2.0 Ga), western Burkina Faso. Precambrian Research, 191, 18-45.

4. Bard, J.-P., 1974. Les grands accidents du craton ouest-africain en Côte d'Ivoire: des décrochements post-éburnéens (?). Comptes Rendus de l'Académie des Sciences, Paris, 278, série D, 2609-2611.

5. Bessoles, B., 1977. Géologie de 1'Afrique. Volume 1: le Craton Ouest Africain. Bureau de Recherches Géologiques et Mininères (BRGM), Memoire, 88, $402 \mathrm{p}$.

6. Block, S., Jessell, M., Aillères, L., Baratoux, L., Bruguier, O., Zeh, A., Bosch, D., Caby, R., \& Mensah, E., 2016a. Lower crust exhumation during Paleoproterozoic (Eburnean) orogeny, NW Ghana, West African Craton: interplay of coeval contractional deformation and extensional gravitational collapse. Precambrian research, 274, 82109.

7. Block, S., Baratoux, L., Zeh, A., Laurent, O., Bruguier, O., Jessell, M., Aillères, L., Sagna, P., Parra-Avilla, L. A., \& Bosch, D., 2016 b. Paleoproterozoic juvenile crust formation and stabilization in the 
south-eastern West African Craton (Ghana); New insights from U-PbHf zircon data and geochemistry. Precambrian research, 287, 1-30.

8. Boher, M., Abouchami, W., Michard, A., Albarede, F., \& Arndt, N., 1992. Crustal growth in West Africa at 2.1 Ga. Journal of Geophysical Research 97, 345-369.

9. Bonhomme, M., 1962. Contribution à l'étude géochronologique de la plate-forme de l'Ouest-Africain. Thèse, Faculté des Sciences, Université Clermont-Ferrand, n5, 62 p.

10. Dabo, M., Aïfa, T., Gassama, I., \& Ngom, P. M., 2018. Thrust to transpression and transtension tectonics during the Paleoproterozoic evolution of Greenstone Belt of Mako, Kédougou-Kéniéba Inlier, Eastern Senegal. Journal of African Earth Sciences, doi : 10.1016/j.jafrearsci.2018.05.010.

11. Daï Bi, S., M., Ouattara, G., Koffi, G., B., Gnansou, A., \& Coulibaly, I., 2018. Mise en évidence de nouvelles structures géologiques dans la région de Brobo (Centre de la Côte d'Ivoire). Aide à la compréhension de la tectonique du Paléoprotérozoïque du Craton Ouest Africain. European Scientific Journal, 14, n 18 p305.

12. Daouda, Y. B., 1998. Lithostratigraphie et Pétrologie des formations birimiennes de Toumodi-Fètêkro: Implication pour l'évolution crustale du Paléoprotérozoïque du Craton Ouest Africain. Thèse, Université d'Orléans $191 \mathrm{p}$.

13. Jessell, M. W., Amponsah, P. O., Baratoux, L., Asiedu, D. K., Loh, G. K., \& Ganne, J., 2012. Crustal-scale transcurrent shearing in the Paleoproterozoic Sefwi-Sunyani-Comoé region, West Africa. Precambrian Research, 212-213, 155-168.

14. Feybesse, J. L., Milési J. P., Johan, V., Doget, A., Calvez, J. Y., Boher, M., \& Abouchami, W., 1989. La limite Archéen /Protérozoïque inférieur de l'Afrique de l'Ouest: une forme de chevauchement majeure antérieure à l'accident de Sassandra; l'exemple de la région d'Odienné et de Touba (Côte d'Ivoire). Comptes Rendus de l'Académie des Sciences, Paris, 1, 309, série II, 1847-1853.

15. Gasquet, D., Barbey, P., Adou, M., \& Paquette, J. L., 2003. Structure, $\mathrm{Sr}-\mathrm{Nd}$ isotope geochemistry and zircon $\mathrm{U}-\mathrm{Pb}$ geochronology of granitoids of Dabakala area (Côte d'Ivoire): evidence for $2.3 \mathrm{Ga}$ crustal growth event in the Palaeoproterozoic of West Africa? Precambrian. Research, 127, 329-354.

16. Grenholm, M., Jessell, M., \& Thébaud, N., 2019. A geodynamic model for the Paleoproterozoic (ca 2.27-1.96 Ga) Birimian Orogen of the southern West African Craton- Insight into an evolving accretionarycollisional orogenic system. Earth-Science Reviews, 192, 138-193. 
17. Kouamelan, A. N., 1996. Géochronologie et Géochimie des formations archéennes et protérozoïques de la dorsale de Man en Côte d'Ivoire: Implication pour la transition Archéen-Protérozoïque. Doctorat Université de. Rennes, Mémoire Géoscience n 73 , Rennes, $293 \mathrm{p}$.

18. Lebrun, E., Miller, J., Thébaud, N., Ulrich, S., \& McCuaig, T. C., 2017. Structural Controls on an Orogenic Gold System : The WorldClass Siguiri Gold District, Siguiri Basin, Guinea, West Africa. Economic Geology, 112, 73-98.

19. Ledru, P., Milési, J. P., Feybesse, J.-L., Dommanget, A., Johan, V., Diallo, M. \& Vinchon, C., 1989. Transcurrent tectonics and polycyclic evolution in the Birrimian, lower Proterozoic of Senegal-Mali (West Africa). Comptes rendus de l'Académie des Sciences, Paris, 308, série 2, 117-122.

20. Lemoine, S., 1982. Le décrochement ductile de Brobo, un linéament éburnéen majeur, son rôle possible dans l'orogenèse éburnéenne en Côte d'Ivoire. Comptes rendus des Séances de l'Académie des sciences, Paris, 295, Série II-601.

21. Lemoine, S. 1988. Evolution géologique de la région de Dabakala (NE de la Côte d'Ivoire) au Protérozoïque inférieur. Thèse de Doctorat Es Sciences Université Clermont-Ferrand, 388 p.

22. Lompo, M., 1991. Etude géologique et structurale des séries birimiennes de la région de Kwademen, Burkina Faso, Afrique de 1 'Ouest. Thèse, Université Clermont II, 180P.

23. Masurel, Q., Thébaud, N., Miller, J., Ulrich, S., Hein, K. A. A., Cameron, G., Béziat, D., Bruguier, O., \& Davis, J. A., 2017. Economic Geology, 112, 23-47.

24. Mattauer, M. 1980. Les déformations des matériaux de l'écorce terrestre. Hermann, 293, rue Lecourbe, 75015 Paris. 493p.

25. Milési, J. P., Ledru, P., Feybesse, J. L., Dommanget, A., \& Marcoux, E., 1992. Early Proterozoic ore deposits and tectonics of Birimian orogenic belt, West Africa. Precambrian Research, 58, 305-344

26. McFarlane, H., Aillère, L., Betts, P. Ganne, J., Baratoux, L., \& Jessell, M., 2017. Nascent Paleoproterozoic episodic collisional orogenesis: the Eburnean Orogeny of the West African Craton. Oral presentation, Rodina 2017, Townsville, Australia, Geological Society of Australia, Abstract, 121, 229-251.

27. Milési, J. P., Feybesse, J. L., Pinna, P., Deschamps, Y., Kampunzu, H., Muhongo, S., Lescuyer, J. L., Le Goff, E., Delor, C., Billa, M., Ralay, F., \& Heinry, C., 2004: Geological map of Africa 1:10,000,000, SIGAfrique project. In 20th Conference of African Geology, Bureau 
de Recherches Géologiques et Minières (BRGM), Orleans France, 2-7 June. http://www.sigafrique.net.

28. Mortimer, J., 1990: Evolution of the early Proterozoic Toumodi volcanic Group and associated rocks, Ivory Coast. PhD. thesis, Portsmouth Polytechnic, $244 \mathrm{p}$.

29. Mortimer, J., 1992. Lithostratigraphic of the early Proterozoic Toumodi Volcanic group in Central Côte d'Ivoire: implication for Birimian stratigraphy models. Journal of African Earth Sciences, 14, 81-91.

30. Passchier, W., \& Trouw, R. A. J., 2005. Microtectonic, 2em Edition Springer, Berlin Heidelberg New York, 289 p.

31. Perrouty, S., Aillères, L., Jessell, M. W., Baratoux, L., Bourassa, Y., \& Crawford, B., 2012. Revised Eburnean geodynamic evolution of the gold-rich southern Ashanti belt, Ghana, with new field and geophysical evidence of pre-Tarkwaian deformations. Precambrian Research, 204-205, 12-39.

32. Pitra, P., Kouamelan, A. N., Ballevre, M., \& Peucat, J. J., 2010. Palaeoproterozoic high-pressure granulite overprint of Archean continental crust: evidence for homogeneous crustal thickening (Man Rise, Ivory Coast). Journal of Metamorphic Geology, 28, 41-58.

33. Pothin, K. B. K., Gioan, P., \& Gronayes, C. C., 2000. Bilan géochronologique du socle précambrien de Côte d'Ivoire. Bioterre, Revue internationale des sciences de la vie et de la terre $1, \mathrm{n}^{\circ} 1,36-47$.

34. Tempier, P., 1986. Le Burkinien: cycle orogénique majeur du protérozoïque inférieur en Afrique de l'Ouest. Publication Occasionnelle du Centre International pour la Formation et les Echanges en Géosciences (CIFEG) «Les formations birimiennes en Afrique de l'Ouest » : 17-23.

35. Trumpette, R., 1973. Le Précambrien supérieur et le Paléozoïque inférieur de l'Adrar de Mauritanie (bordure occidentale du bassin de Taoudéni, Afrique de l'Ouest). Un exemple de sédimentation de craton. Etude stratigraphique et sédimentologique. Thèse de Doctorat Ès-Sciences, Université Aix-Marseille III, Travaux du Laboratoire des. Sciences de la Terre, St. Jérôme, Marseille, Bulletin 7, 702 p.

36. Vidal, M. \& Guibert, Ph., 1984. Un nouveau décrochement ductile nord-sud dans le Birimien d'Afrique de l'Ouest: le couloir de cisaillement senestre de Wango-Fitini (Côte d'Ivoire). Comptes Rendus de l'Académie des Sciences, Paris, 299, série II, 1085-1090.

37. Vidal, M. \& Alric, G., 1994. The Palaeoproterozoic (Birimian) of Haute-Comoé in the West African craton, Ivory Coast: a transtension back-arc basin. Precambrian Research, 65, 207-229. 
38. Vidal, M., Delor, C., Pouclet, A., Simeon, Y. \& Alric, G., 1996: Evolution géodynamique de l'Afrique de l'Ouest entre 2,2 Ga et $2 \mathrm{Ga}$ : le style « archéen » des ceintures vertes et des ensembles sédimentaires birimiens du nord-est de la Côte d'Ivoire. Bulletin de la Société géologique de France, 167, n 3, 307-319.

39. Yace, I., 1982. Etude du volcanisme Eburnéen dans les parties centrales et méridionales de la chaîne Précambrienne de Fettêkro. Ministère des Mines, République de Côte d'Ivoire, 156 p.

40. Yace, I., 1984. Le précambrien de l'Afrique de l'Ouest et ses corrélations avec le Brésil oriental. Rapport final, Publication Programme International de Corrélation Géologique (PICG)-Centre International pour la Formation et les Echanges en Géosciences (CIFEG), n², Paris, $28 \mathrm{p}$. 